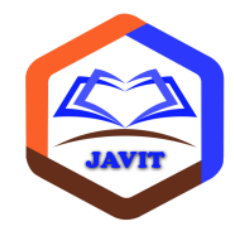

JURNAL VOKASI INFORMATIKA

(JAVIT)

Terbit online pada laman web jurnal: http://javit.ppj.unp.ac.id DOI: https://doi.org/10.24036/javit.v1i2.21

ISSN: $2775-6807$

Vol. 1 No. 2 (2021) 26 - 30

\title{
Kontribusi Gaya Belajar dan Pemanfaatan Google Classroom Pada Masa Pandemi Covid-19 Terhadap Hasil Belajar Siswa Kelas XII Teknik Komputer Jaringan SMK Negeri 5 Padang \\ 1,* Cindy Oktaviani, ${ }^{2}$ Dedy Irfan \\ ${ }^{1,2}$ Jurusan Teknik Elektronika, Universitas Negeri Padang \\ *Coressponding author e-mail: cindyoktaviani373@gmail.com
}

\begin{abstract}
Abstrak
Tujuan analisis data yaitu untuk mengungkapkan Kontribusi Gaya Belajar, Pemanfaatan Google Classroom Terhadap Hasil Belajar Siswa Kelas XII Teknik Komputer Jaringan SMK Negeri 5 Padang. populasi untuk menganalisis data ini 52 siswa . penelitian ini termasuk jenis penelitian deskriptif korelasional. penelitian ini memakai teknik Random Sampling yang berjumlah 36 siswa. Data penelitian ini didapatkan dari guru Teknik Komputer Jaringan SMK Negeri 5 Padang dan didapatkan berdasarkan angket. Hasil yang didapatkan dari pengolahan data yaitu: (1) gaya belajar, pemanfaatan google classroom berkontribusi $0,0256 \%$; (2) Gaya belajar berkontribusi 0,081\%; (3) Pemanfaatan google classroom berkontribusi $0,01 \%$. kesimpulan yang didapatkan adalah terdapat kontribusi gaya belajar dan pemanfaatan google classroom terhadap hasil belajar siswa SMK Negeri 5 Padang.
\end{abstract}

Kata kunci : Analisis Data, Gaya Belajar, Penelitian, Pemanfaatan Google Classroom, Hasil Belajar.

(C) Lisensi: Creative Commons Attribution 4.0 International (CC BY 4.0) 


\section{Pendahuluan}

Pada akhir tahun 2019 merupakan ujian bagi semua Negara dibelahan dunia. Hal ini disebabkan menyebarnya wabah penyakit bernama Covid-19 yang mulai berkembang di Wuhan, Cina. World Health Organization (WHO) menyatakan wabah penyebaran virus ini sebagai pandemik dunia saat ini.

Melalui Surat Edaran Mendikbud RI No. 3 Tahun 2020 tentang pencegahan Covid-19 pada satuan pendidikan dan kebudayaan. Dalam surat edaran tersebut berisi tentang pelaksanaan pembelajaran jarak jauh sesuai dengan kondisi sekolah masing-masing [1].

Tidak terkecuali di SMK Negeri 5 Padang menerapkan pembelajaran jarak jauh dengan sistem pembelajaran daring. Menanggapi respon kebijakan belajar dari rumah maka Jurusan Teknik Komputer Jaringan SMK Negeri 5 Padang menggunakan media pembelajaran berbasis online berupa google classroom yang dapat memudahkan proses pembelajaran tetap berjalan.

Berdasarkan hasil observasi yang dilaksanakan di SMK Negeri 5 Padang diketahui bahwa pembelajaran daring berdampak pada minat belajar siswa kelas XII Teknik Komputer Jaringan yang mana sangat terlihat dari sedikitnya siswa yang membaca materi yang disediakan di google classroom dan sedikitnya siswa yang mengumpulkan tugas serta sedikitnya siswa yang berpartisipasi untuk mengikuti pembelajaran melalui google classroom.

Tabel 1. Data Hasil Belajar Ujian Tengah Semester Ganjil Siswa Kelas XII TKJ

\begin{tabular}{lcccccc}
\hline & & & \multicolumn{3}{c}{ Nilai Ujian Tengah Semester } \\
\cline { 3 - 7 } No & \multirow{2}{*}{ Kelas } & $\begin{array}{c}\text { Jumlah } \\
\text { siswa }\end{array}$ & $\begin{array}{c}\text { Belum Tuntas } \\
<\mathbf{7 0}\end{array}$ & \multicolumn{2}{c}{ Tuntas $\geq 70$} \\
\cline { 3 - 7 } & & & $\begin{array}{c}\text { Jumlah } \\
\text { Siswa }\end{array}$ & $\%$ & $\begin{array}{c}\text { Jumlah } \\
\text { Siswa }\end{array}$ & $\%$ \\
\hline 1 & XII TKJ 1 & 31 & 10 & $32 \%$ & 21 & $68 \%$ \\
\hline 2 & XII TKJ 2 & 21 & 9 & $43 \%$ & 12 & $57 \%$ \\
\hline & Jumlah & 52 & 19 & $37 \%$ & 33 & $63 \%$ \\
\hline
\end{tabular}

Sumber: Guru TKJ SMK Negeri 5 Padang

Data pada tabel 1 menunjukkan $37 \%$ dari 52 siswa memperoleh nilai dibawah KKM, dan siswa $63 \%$ dari 52 siswa memperoleh nilai diatas KKM.

Sekolah mempunyai kebijakan masing-masing dalam upaya kualitas belajar siswa tentunya dalam hal pembelajaran daring, mereka akan berusaha membuat pembelajaran efektif walaupun belajar melalui sistem daring. Pembelajaran yang menyenangkan dan mampu memberi kebebasan pada siswa untuk mengembangkan ide pribadi akan meningkatkan minat belajar. Dukungan minat belajar sangat dibutuhkan untuk terciptanya pembelajaran efektif.

\section{Tinjauan Pustaka}

Google Classroom merupakan sistem manajemen pembelajaran untuk sekolah-sekolah dengan tujuan memudahkan pembuatan, pendistribusian dan penilaian tugas secara paperless[2].

Gaya belajar adalah cara yang cenderung dipilih siswa untuk bereaksi dan menggunakan perangsangperangsang dalam menyerap dan kemudian mengatur serta mengolah informasi pada proses belajar [3].

Antara siswa yang satu dengan siswa yang lain memiliki gaya belajar yang berbeda-beda. Hal ini tergantung dari kenyamanan masing-masing siswa dalam menerima informasi yang diperoleh dalam proses belajar. Ada tiga tipe gaya belajar yaitu: (1) visual: belajar melalui apa yang mereka lihat, (2) audititorial: belajar melalui apa yang mereka dengar dan (3) kinestik: belajar lewat gerakan maupun sentuhan [4].

Jadi dapat diambil makna bahwa dalam situasi tertentu diperlukan gaya belajar yang tertentu pula. Hal ini mengandung arti bahwa gaya belajar yang dilakukan seseorang tergantung pada situasi belajarnya. Seorang siswa akan memperoleh hasil belajar yang baik apabila siswa tersebut belajar dengan teratur dan menggunakan gaya belajar yang tepat.

Sesuai dengan uraian diatas penulis terdorong untuk melakukan penelitian dengan judul "Kontribusi Gaya Belajar Dan Pemanfaatan Google Classroom Pada Masa Pandemi Covid-19 Terhadap Hasil Belajar Siswa Kelas XII Teknik Komputer Jaringan SMK NEGERI 5 PADANG”.

\section{Metode Penelitian}

Metode yang digunakan dalam Penelitian ini termasuk penelitian deskriptif dan korelasional untuk mengumpulkan data tentang fakta yang ada saat penelitian dilaksanakan.

Variabel penelitian ini meliputi Gaya Belajar (X1) dan pemanfaatan google classroom (X2) sebagai variabel bebas, dan hasil belajar (Y) sebagai variabel terikat.

Pada penelitian ini yang menjadi populasi adalah siswa kelas XII jurusan teknik komputer jaringan yang berjumlah 52 siswa.

Tabel 2. Populasi Dari Penelitian

\begin{tabular}{ccccc}
\hline No & Kelas & Populasi & Sampel & $\begin{array}{c}\text { Proporsi } \\
\text { Sampel }\end{array}$ \\
\hline \multirow{2}{*}{1} & XII TKJ 1 & 31 & $\begin{array}{c}(31 / 52) \mathrm{x} \\
35\end{array}$ & 21 \\
2 & XII TKJ 2 & 21 & $\begin{array}{c}(21 / 52) \mathrm{x} \\
35\end{array}$ & 15 \\
& & & 36 \\
\hline \multicolumn{5}{c}{ Jumlah sampel }
\end{tabular}

Teknik pengambilan sampel yang digunakan pada penelitian ini yaitu secara acak. 
Tabel 3. Sampel dari Penelitian

\begin{tabular}{ccc}
\hline No & Kelas & Jumlah siswa \\
\hline 1 & XII TKJ 1 & 31 siswa \\
\hline 2 & XII TKJ 2 & 21 siswa \\
\hline & Jumlah & 52 siswa \\
\hline
\end{tabular}

$$
\mathrm{Y}=\alpha+b 1 \mathrm{X}_{1}+\mathrm{b} 2 \mathrm{X}_{2}
$$

Sebelum uji hipotesis maka harus menghitung Koefisien Korelasi Berganda (nilai R) dengan rumus yaitu:

$$
\mathrm{R}_{\mathrm{X} 1 \mathrm{X} 2 \mathrm{Y}}=\sqrt{\frac{\mathrm{b}_{1} \sum \mathrm{X}_{1} \mathrm{Y}+\mathrm{b}_{2} \sum \mathrm{X}_{2} \mathrm{Y}}{\sum \mathrm{Y}^{2}}}
$$

Untuk menghitung koefisien korelasi parsial dengan rumus

$$
\begin{aligned}
& \text { Menghitung } r_{X_{2}\left(X_{1} Y\right)} \\
& r_{X_{2}}\left(X_{1} Y\right)=\frac{r_{X_{1} Y}-r_{X_{2} Y \cdot r_{1} X_{2}}}{\sqrt{\left(1-r_{X_{2} Y}^{n}\right) \cdot\left(1-r_{X_{1} X_{2}}^{n}\right)}} \\
& \text { Menghitung } r_{X_{1}\left(X_{2} Y\right)} \\
& r_{X_{1}(2 Y)}=\frac{r X_{2} Y-r_{X_{1} Y} r_{X_{1} X_{2}}}{\sqrt{\left(1-r_{X_{1} Y}^{2}\right)\left(1-r_{X_{1} X_{2}}^{2}\right)}}
\end{aligned}
$$

Selanjutnya dilakukan uji $\mathrm{F}$ untuk mengetahui pengaruh variabel bebas terhadap variabel terikat

$$
F_{\text {hitung }}=\frac{R^{2} / k}{\left(1-R^{2}\right)(n-k-1)}
$$

Selanjutnya dilakukan uji $\mathrm{t}$ untuk melihat pengaruh variabel bebas dan variabel terikat secara parcial [5]. Dengan rumus:

$$
t_{\text {hitung }}=\frac{y_{\text {parsiar } \sqrt{n-8}}}{\sqrt{1-y_{\text {parsial }}^{2}}}
$$

\section{Hasil dan Pembahasan}

Data yang didapatkan dari hasil analisis yaitu: deskripsi data gaya belajar dan pemanfaatan google

\begin{tabular}{|c|c|c|c|c|}
\hline \multirow[b]{2}{*}{ No } & \multirow[b]{2}{*}{ Variabel } & \multicolumn{3}{|c|}{ Pemanfaatan } \\
\hline & & $\begin{array}{c}\text { Gaya } \\
\text { Belajar }\left(X_{1}\right)\end{array}$ & $\begin{array}{c}\text { Google } \\
\text { Classroom } \\
\left(\mathrm{X}_{2}\right) \\
\end{array}$ & $\begin{array}{c}\text { Hasil } \\
\text { belajar(Y) }\end{array}$ \\
\hline 1 & $\mathrm{~N}$ & 36 & 36 & 36 \\
\hline 2 & Mean & 51,05 & 58,03 & 73,58 \\
\hline 3 & Median & 51,50 & 57,50 & 72,00 \\
\hline 4 & Mode & 57 & 64 & 67 \\
\hline 5 & Std.Deviation & 4,702 & 7,125 & 9,545 \\
\hline 6 & Variance & 22,111 & 50,771 & 91,107 \\
\hline 7 & Range & 18 & 30 & 35 \\
\hline 8 & Minimum & 39 & 48 & 60 \\
\hline 9 & Maximum & 57 & 78 & 95 \\
\hline 10 & Sum & 1838 & 2089 & 2649 \\
\hline \multicolumn{5}{|c|}{ Tabel 5. Distribusi Frekuensi Skor $\left(X_{1}\right)$} \\
\hline NO & \multicolumn{3}{|c|}{ Kelas Interval } & $\mathbf{f}$ \\
\hline 1 & \multicolumn{3}{|c|}{$39-41$} & 1 \\
\hline 2 & \multicolumn{3}{|c|}{$42-44$} & 4 \\
\hline 3 & \multicolumn{3}{|c|}{$45-47$} & 4 \\
\hline 4 & \multicolumn{3}{|c|}{$48-50$} & 5 \\
\hline 5 & \multicolumn{3}{|c|}{$51-53$} & 11 \\
\hline 6 & \multicolumn{3}{|c|}{$54-56$} & 6 \\
\hline 7 & \multicolumn{3}{|c|}{$57-59$} & 5 \\
\hline \multicolumn{4}{|c|}{ Jumlah } & 36 \\
\hline
\end{tabular}
classroom, serta hasil belajar siswa. Uji prasyarat penelitian ini yaitu uji normalitas, uji homogenitas, uji liinearitas, uji multikolinearitas, uji hipotesis dan pembahasan.

Data yang ditunjukkan dalam pendeskripsian data terlihat seperti tabel 4.
Tabel 4. Data X1, X2, Y

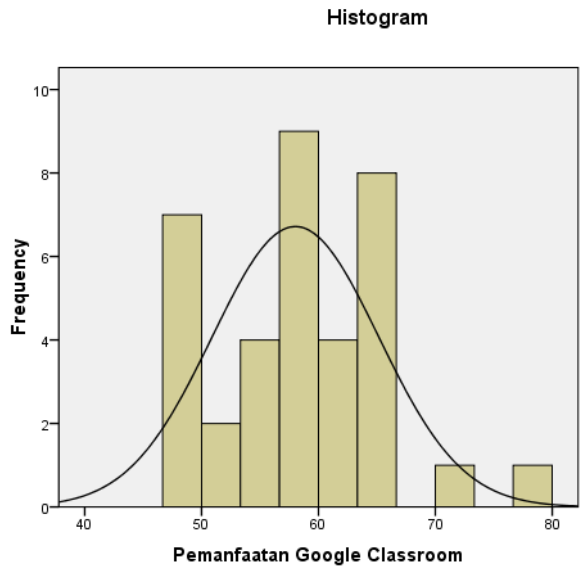

Gambar 1. Histogram dan Kurva Normal Skor Gaya Belajar $\left(\mathbf{X}_{1}\right)$

Tabel 6. Distribusi Frekuensi Skor $\left(\mathrm{X}_{2}\right)$

\begin{tabular}{ccc}
\hline & Tabel 6. Distribusi Frekuensi Skor $\left(\mathbf{X}_{\mathbf{2}}\right)$ \\
\hline 1 & Kelas Interval & $\mathbf{F}$ \\
\hline 2 & $48-52$ & 9 \\
\hline 3 & $53-57$ & 9 \\
\hline 4 & $58-62$ & 7 \\
\hline 5 & $63-67$ & 9 \\
\hline 6 & $68-72$ & 1 \\
\hline 7 & $74-78$ & 1 \\
\hline & $79-83$ & 0 \\
\hline
\end{tabular}




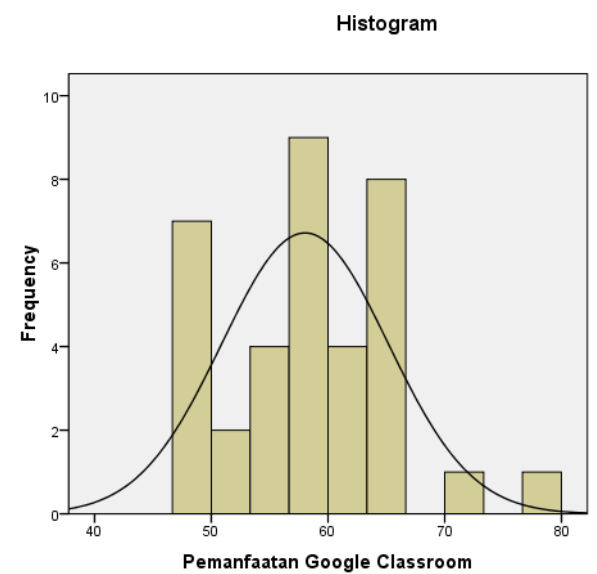

Gambar 2. Histogram dan Kurva Normal Skor pemanfaatan google classroom (X2)

\begin{tabular}{ccc}
\multicolumn{3}{c}{ Tabel 7. Distribusi Frekuensi Skor $(\mathbf{Y})$} \\
\hline NO & Kelas Interval & $\mathbf{F}$ \\
\hline 1 & $60-65$ & 8 \\
\hline 2 & $66-71$ & 8 \\
\hline 3 & $72-77$ & 9 \\
\hline 4 & $78-83$ & 6 \\
\hline 5 & $84-89$ & 2 \\
\hline 6 & $90-95$ & 3 \\
\hline 7 & $96-101$ & 0 \\
\hline & Jumlah & 36 \\
\hline
\end{tabular}

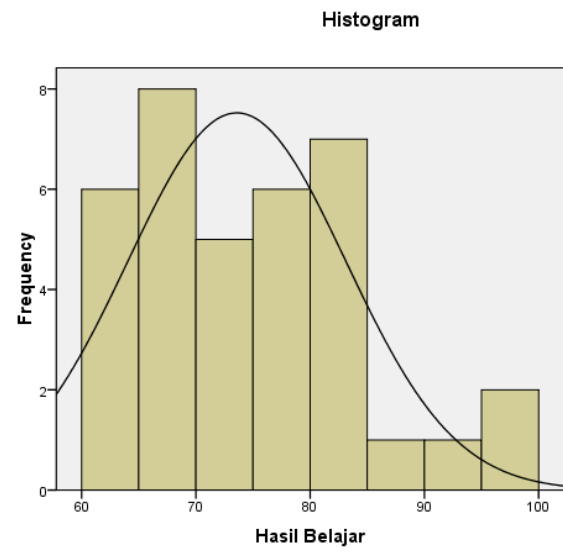

Gambar 3. Nilai histogram variabel $Y$

Tabel 8. Uji Normalitas melalui Chi-Square Test Statistics

\begin{tabular}{|l|r|r|r|}
\hline & \multicolumn{1}{|c|}{$\begin{array}{c}\text { Gaya } \\
\text { Belajar }\end{array}$} & $\begin{array}{c}\text { Pemanfaatan } \\
\text { Google } \\
\text { Classroom }\end{array}$ & \multicolumn{1}{c|}{$\begin{array}{c}\text { Hasil } \\
\text { Belajar }\end{array}$} \\
\hline Chi-Square & $11.444^{\mathrm{a}}$ & $20.667^{\mathrm{b}}$ & $8.389^{\mathrm{c}}$ \\
df & 13 & 14 & 16 \\
Asymp. Sig. & .574 & .110 & .936 \\
\hline \multicolumn{2}{|c|}{ Untuk uji normalitas } & \multicolumn{2}{|c|}{ menunjukkan nilai }
\end{tabular}
signifikansi probabilitas gaya belajar $\left(\mathrm{X}_{1}\right)$ adalah 0,574, pemanfaatan google classroom $\left(\mathrm{X}_{2}\right)$ berjumlah 0,110 dan hasil belajar siswa (Y) 0,936. Pendapatan semua variabel besar dari 0,05 maka data pada variabel gaya belajar, pemanfaatan google classroom dan hasil belajar siswa berdistribusi normal.

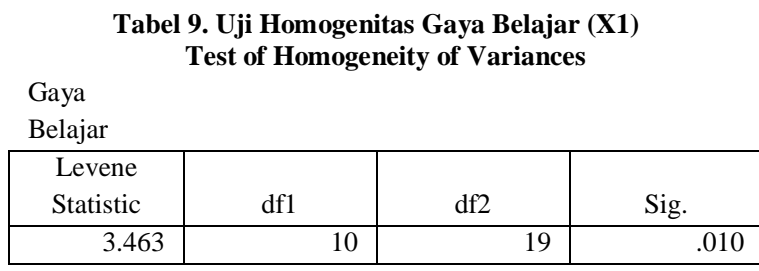

Tabel 10. Uji Homogenitas Pemanfaatan Google Classroom (X2)

Test of Homogeneity of Variances

Pemanfaatan Google Classroom

\begin{tabular}{|c|c|c|c|}
\hline $\begin{array}{l}\text { Levene } \\
\text { Statistic }\end{array}$ & df1 & $\mathrm{df} 2$ & Sig. \\
\hline 1.948 & 10 & 19 & 0101 \\
\hline
\end{tabular}

Untuk uji homogenitas menunujukkan nilai gaya belajar adalah 0,010 dan nilai pemanfaatan google classroom adalah 0,101.

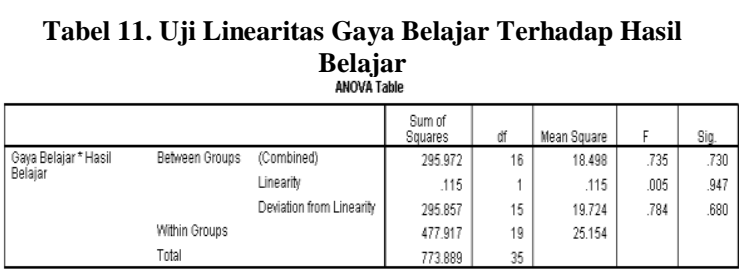

Tabel 12. Uji Linearitas Pemanfaatan Google Classroom Terhadap Hasil Belajar

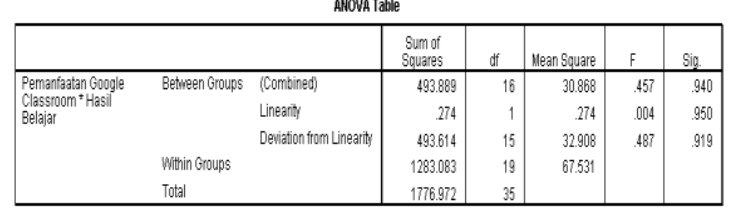

Untuk uji linearitas menunjukkan nilai gaya belajar terhadap hasil belajar siswa adalah 0,947, nilai pemanfaatan google classroom terhadap hasil belajar siswa adalah 0,950. Nilai kedua variabel independen lebih dari 0,05 maka antara variabel gaya belajar, variabel pemanfaatan google classroom dengan variabel hasil belajar siswa memiliki hubungan yang linear.

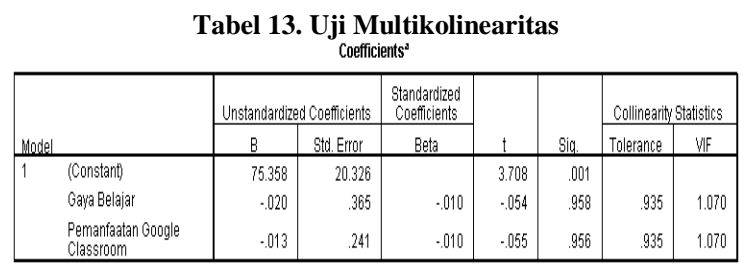

Berdasarkan pengujian multikolinearitas menunjukkan bahwa hubungan gaya belajar $\left(\mathrm{X}_{1}\right)$, pemanfaatan google classroom $\left(\mathrm{X}_{2}\right)$ dengan hasil belajar siswa adalah 1,070 dengan toleransi 0.935 . 
skor VIF kurang dari 5 maka tidak terlihat ada permasalahan yang multikolinearitas pada model regresi.

Tabel 14. Hasil analisis regresi $X 1, X 2$, terhadap $Y$ coefficierts

\begin{tabular}{|c|c|c|c|c|c|c|c|c|c|c|c|}
\hline \multirow{2}{*}{\multicolumn{2}{|c|}{ Wodtel }} & \multicolumn{2}{|c|}{ Unstandarlizes Coeficierts } & \multirow{2}{*}{\begin{tabular}{|c|}
$\begin{array}{c}\text { Standardiced } \\
\text { Coeficierts }\end{array}$ \\
Beta \\
\end{tabular}} & \multirow[b]{2}{*}{1} & \multirow[b]{2}{*}{ Silo } & \multicolumn{3}{|c|}{ Conerelajons } & \multicolumn{2}{|c|}{ Colinesintit Statisitics } \\
\hline & & B & Stot Emor & & & & Zen-oriter & Patial & Pant & Tolerance & MF \\
\hline 1 & (Constatht & 75.358 & 20.326 & & 3.708 & .001 & & & & & \\
\hline & Giapelajar & .020 & .365 & .010 & .054 & .958 & .012 & .009 & .009 & .935 & 1.070 \\
\hline & $\begin{array}{l}\text { Pemanafiatan Govgle } \\
\text { Classtoom }\end{array}$ & .013 & .241 & .010 & .055 & .956 & .012 & .010 & .010 & .935 & 1.070 \\
\hline
\end{tabular}

Dari analisis regresi berganda hasil yang didapatkan yaitu:

$$
\mathrm{Y}=75,358+0,020 \mathrm{X}_{1}+0,013 \mathrm{X}_{2}
$$

Jika variabel gaya belajar mendapati kenaikan, maka hasil belajar siswa (Y) naik 0,020. Apabila variabel pemanfaatan google classroom mendapati kenaikan, maka hasil belajar siswa naik 0,013 .

Tabel 15. Ringkasan model Model Summary

\begin{tabular}{|c|c|c|c|c|c|c|c|c|c|}
\hline \multirow[b]{2}{*}{ Mods } & \multirow[b]{2}{*}{$\mathrm{F}$} & \multirow[b]{2}{*}{ RSguare } & \multirow[b]{2}{*}{$\begin{array}{l}\text { AdjustedR } \\
\text { Gguare }\end{array}$} & \multirow[b]{2}{*}{$\begin{array}{c}\text { Stdd Emor of } \\
\text { the Esimale }\end{array}$} & \multicolumn{5}{|c|}{ Chanye Stailstics } \\
\hline & & & & & $\begin{array}{l}\text { R Square } \\
\text { changeg }\end{array}$ & FChange & off & $d+2$ & Sig. F change \\
\hline 1 & $.016^{2}$ & .000 & -.060 & 9.829 & .000 & .004 & 2 & 33 & .996 \\
\hline
\end{tabular}

Skor korelasi simultan gaya belajar, pemanfaatan google classroom dengan hasil belajar siswa (Y) adalah 0,016. persentase gaya belajar dan pemanfaatan google classroom terhadap hasil belajar siswa bisa dihitung $r^{2} x 100 \%=(0,016)^{2} x$ $100 \%=0,0256 \%$.

Secara parcial Gaya belajar berkontribusi dengan hasil belajar siswa adalah $\mathrm{r}^{2} \times 100 \%=(0,009)^{2} \mathrm{x}$ $100 \%=0,0081 \%$, pemanfaatan google classroom berkontribusi dengan hasil belajar siswa adalah $\mathrm{r}^{2} \mathrm{x}$ $100 \%=(0,010)^{2} \times 100 \%=0,01 \%$.

\begin{tabular}{|c|c|c|c|c|c|}
\hline \multicolumn{6}{|c|}{$\begin{array}{c}\text { Tabel 16. Uji F } \\
\text { ANNOVA }^{\text {b }}\end{array}$} \\
\hline Model & $\begin{array}{l}\text { Sum of } \\
\text { Squares }\end{array}$ & df & $\begin{array}{c}\text { Mean } \\
\text { Square }\end{array}$ & $\mathbf{F}$ & Sig. \\
\hline $1 \quad$ Regression & .770 & 2 & .385 & .004 & $.996^{\mathrm{a}}$ \\
\hline Residual & 3187.980 & 33 & 96.605 & & \\
\hline Total & 3188.750 & 35 & & & \\
\hline
\end{tabular}

Uji hipotesis pertama menunjukkan nilai $\mathrm{F}_{\text {hitung }}=$ 0,004 dengan signifikan adalah 0,996, sehingga dikatakan signifikan apabila >0,05 $(0,996>0,05$. Gaya belajar dan pemanfaatan google classroom memberikan kontribusi terhadap hasil belajar siswa adalah $r^{2} \times 100 \%=(0,016)^{2} \times 100 \%=0,0256 \%$.

Uji hipotesis kedua menunjukkan nilai $\mathrm{t}_{\text {hitung }} \mathrm{X}_{1}$ adalah 0,054 dengan signifikan 0,958, sehingga $0,958,>0,05$. Gaya belajar berkontribusi $\mathrm{r}^{2} \times 100 \%$ $=(0,009)^{2} \times 100 \%=0,0081 \%$

Uji hipotesis III menunjukkan nilai $\mathrm{t}_{\text {hitung }} \mathrm{X}_{2}$ adalah 0,055 dengan signifikansi 0,956. Maka 0,956>0,05. Pemanfaatan google classroom berkontribusi $\mathrm{r}^{2} \mathrm{x}$ $100 \%=(0,010)^{2} \times 100 \%=0,01 \%$.

\section{Kesimpulan}

Berdasarkan analisis data dan hasil penelitian yang dilakukan, dapat diambil kesimpulan bahwa:

1. Gaya Belajar dan Pemanfaatan Google Classroom memberikan kontribusi 0,0256 \% terhadap hasil belajar siswa.

2. Gaya Belajar memberikan kontribusi 0,0081 $\%$ terhadap hasil belajar siswa.

3. Pemanfaatan google classroom memberikan kontribusi $0,01 \%$ terhadap hasil belajar siswa.

Berdasarkan hasil kesimpulan dan hasil pembahasan, adapun saran yang dapat diberikan yaitu:

1. Sebagai seorang guru, diharapkan penelitian ini dijadikan sebagai pedoman untuk meningkatkan pelaksanaan pembelajaran.

2. Sebagai seorang siswa hasil penelitian ini dapat dijadikan pedoman untuk dapat mengoptimalkan pemanfaatan google classroom selama proses pembelajaran daring berlangsung.

Untuk peneliti lain agar dapat menjadikan penelitian ini sebagai bahan perbandingan dan dapat mengembangkan kembali supaya terlihat lebih baik.

\section{Daftar Rujukan}

[1] Menteri Pendidikan dan Kebudayaan. 2020. Surat Edaran Nomor 3 Tahun 2020 Tentang Pencegahan Corona Virus Disease (Covid-19) Pada Satuan Pendidikan.

[2] Afrianti, W. E. (2018). Penerapan Google Classroom Dalam Pembelajaran Akuntansi (Studi Pada Program Studi Akuntansi Universitas Islam Indonesia).

[3] Budiarti, I., dan Jabar, A. (2016). Pengaruh gaya belajar terhadap hasil belajar matematika siswa kelas VIII SMPN 2 Banjarmasin tahun ajaran 2015/2016. Math Didactic: Jurnal Pendidikan Matematika, 2(3), 142-147.

[4] Ningrat, S. P., Tegeh, I. M., dan Sumantri, M. (2018). Kontribusi Gaya Belajar Dan Motivasi Belajar Terhadap Hasil Belajar Bahasa Indonesia. Jurnal Ilmiah Sekolah Dasar, 2(3), 257-265

[5] Riduwan. 2012. Pengantar Statistika Sosial. Bandung: Alfabeta. 